\title{
LAS REVISTAS DE ACTUALIDAD GERMEN DE LA CRÓNICA LITERARIA. ALGUNAS CALAS EN LA EVOLUCIÓN DE UN GÉNERO PERIODÍSTICO ENTRE 1845 Y 1868
}

\author{
Cecilio AlONSO \\ cecilnico@msn.com \\ UNED Alzira-Valencia
}

\section{Resumen}

Ensayo de aproximación diacrónica a las secciones de actualidad en publicaciones literarias e ilustradas hasta 1868, bajo la hipótesis de que en ellas se incubó la crónica literaria moderna afirmada en el último cuarto del siglo XIX. Se presta atención a los autores más destacados en este proceso, a sus tendencias informativas y retóricas, en relación a tres modelos conceptuales de periódicos — «Pintorescos», «Universales»e «Ilustraciones». En ellos la construcción de la imagen nacional trata de ajustarse a los grandes referentes europeos.

Palabras clave: «Revista de la Semana», crónica, prensa ilustrada siglo XIX, Francisco Navarro Villoslada, Ángel Fernández de los Ríos, Ramón de Navarrete, José María de Antequera, Antonio Flores, Nemesio Fernández Cuesta, León Galindo y de Vera, Benito Pérez Galdós, Gustavo Adolfo Bécquer.

\begin{abstract}
This essay is a diachronic approach to the current affairs sections in literary and illustrated magazines and journals until 1868, and it puts forward the following hypothesis: it was in these publications that the modern literary chronicle was born, which definitely developed in the last quarter of the $20^{\text {th }}$ century. The article focuses on the most outstanding authors in this process, on their informative and rhetorical trends, in relation to three conceptual models of periodicals - «Pintorescos» (Picturesque), «Universales» (Universal) and «Ilustraciones» (Illustrations).
\end{abstract}


Keywords: «Revista de la Semana», chronicle, 19th century illustrated press, Francisco Navarro Villoslada, Ángel Fernández de los Ríos, Ramón de Navarrete, José María de Antequera, Antonio Flores, Nemesio Fernández Cuesta, León Galindo y de Vera, Benito Pérez Galdós, Gustavo Adolfo Bécquer.

Desde el decenio de 1840, las secciones de actualidad informativa se desarrollaron por la conveniencia de dinamizar parcialmente el contenido estático de las publicaciones ilustradas apellidadas «pintorescas», en las que se requería alguna referencia visual —retratista, monumental, paisajista, faunística, industrial o de ficción - relacionada con el texto del artículo correspondiente. A través de una práctica estimulada por los avances de la xilografía nacional aplicados a las artes de imprimir y por el comercio europeo de grabados, se fue forjando un género endógeno, propiamente periodístico, que tuvo su decisivo campo de pruebas en los periódicos subtitulados «universales» que aspiraban a acercarse a la órbita de las primeras Ilustraciones europeas. Salvo en casos eminentes — Galdós (Hoar, 1968; Shoemaker, 1972) y Bécquer (Ortega, 2003) - este género ha tenido en su contra el inconveniente de que no se coleccionó en libros por resolverse en su propia instantaneidad informativa. La falta de nuevas dimensiones de lectura con el paso del tiempo ha incrementado su opacidad y reducido la curiosidad en los analistas de la literatura periodística que tienden a verlos como cuerpos extraños de menor entidad, por ser «una especie de mezcla de todo» (Piudo, 1971: 3).

En el arco temporal de un decenio el modelo francés del Magasin Pittoresque (1833) dejó pasó al de L'Illustration. Journal Universel (1843). En la proyección española de tal proceso, producido con algún retraso entre 1836 y 1849, corresponde al término pintoresco la nota romántica nacional, el descubrimiento de lo local, y al término universal la espita a través de la cual el romanticismo en crisis se abre a un cierto cosmopolitismo de sesgo realista, sin que quepa hablar de incompatibilidad entre ambos términos que coexistieron durante algunos años chirriando equívocamente en las cabeceras de destacadas publicaciones al tiempo que se iba concretando el difícil deslinde entre ambos conceptos de la cultura periodística.

Por un lado, los revisteros tenían que resolver su trabajo de acuerdo con una actualidad previsible basada en la sucesión de acontecimientos naturales o litúrgicos: nieves invernales, lluvias abrileñas y mayos floridos; navidades, estrechos de reyes, carnavales, cuaresmas, semanas santas, verbenas veraniegas y días de difuntos. Por otra parte, debían captar eventos de la vida social que se manifestaban en una espiral escalonada espacialmente: Madrid, España, Europa. El foco podía extenderse o acortarse a discreción, lo mismo 
que se podía seleccionar el objeto, difuminarlo o detallarlo con exactitud. Lo definitorio en estas revistas era la versatilidad determinada por el principio de síntesis y de adecuación a las circunstancias. En rigor se trataba de un género informativo elaborado bajo un concepto de lo literario muy flexible donde podían confluir, bajo diversos epígrafes, la crónica factual, el cuadro de costumbres, el esbozo satírico la reseña crítica, teatral o musical y el excurso lírico o humorístico, como puede observarse en el siguiente resumen comparativo de secciones de actualidad en las siete publicaciones que nos sirven de fuente:

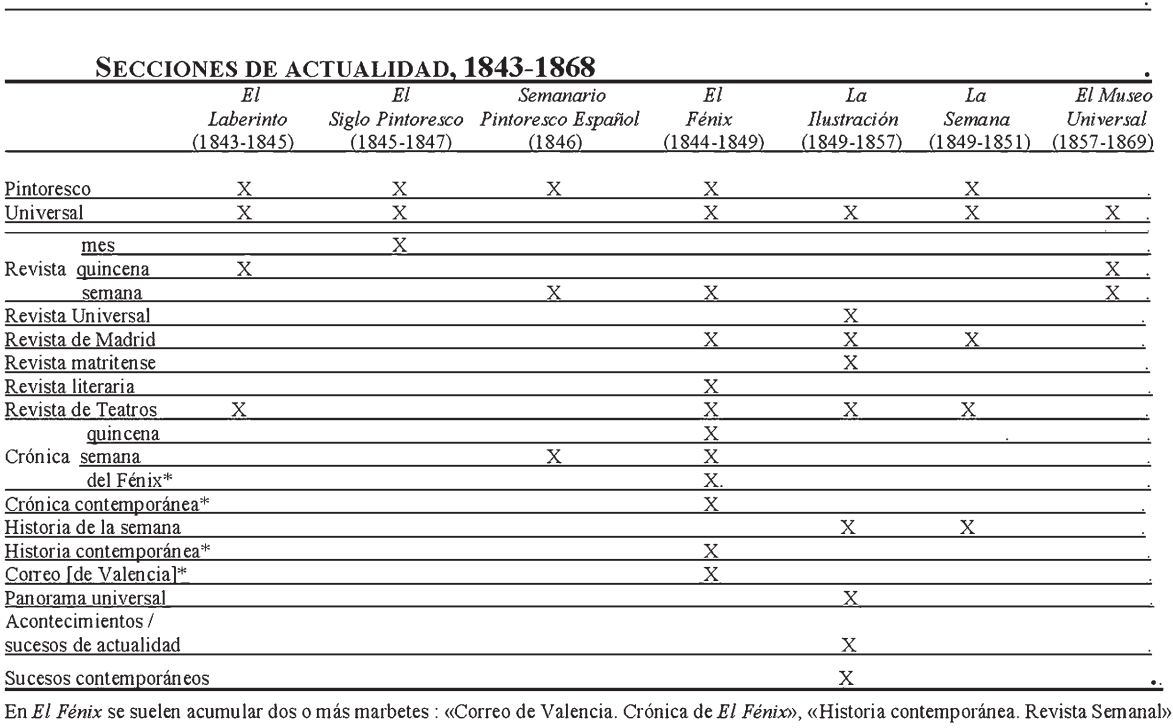

Nuestra selección de cabeceras, que atiende a la calidad y significado histórico de los medios escogidos, trata de reflejar los años de transición entre el antiguo concepto «pintoresco» y la moderna aspiración «universal», coincidentes con el desarrollo del moderantismo político. Como puede verse, sólo uno de estos periódicos se mantiene fiel a su definición originaria: el Semanario Pintoresco Español, traído aquí puntualmente por la inestabilidad conceptual que vivió en 1846. Las cuatro cabeceras que comparten ambos rasgos — pintorescos y universales - se debaten en la fase de indefinición que precede al alumbramiento del cambio. Por último, La Ilustración y El Museo Universal eluden la nota pintoresca en ademán de haber superado el deslinde entre lo viejo y lo nuevo.

El germen de la crónica literaria moderna que se impuso a finales del XIX puede buscarse en las secciones de actualidad — «Historias» o «revistas» de 
la semana, de la quincena o del mes, «crónicas» de varia factura, «correos» o «sucesos contemporáneos»...- que, en mayor o menor medida, se insertaron desde 1843 en El Laberinto del editor Ignacio Boix bajo la dirección de Antonio Flores y de Antonio Ferrer del Rio; en la encrucijada empresarial y artística de El Siglo Pintoresco y el Semanario Pintoresco, entre 1845 y 1847, donde alternaron el grabador Vicente Castelló, el novelista Navarro Villoslada, el periodista Fernández de los Ríos y el impresor Baltasar González; en El Fénix, periódico literario valenciano dirigido por Rafael de Carvajal y por Luis Miquel y Roca (1844-1849), o en La Semana (1849-1851) del editor Francisco de P. Mellado con la colaboración de José María de Antequera. A partir de 1849, Ángel Fernández de los Ríos, que conservaba la rentable propiedad del Semanario Pintoresco sin despojarlo de su naturaleza romántica moderada, comenzó a desarrollar un amplio programa editorial progresista destinado a extender el consumo mesocrático de letra impresa. Así se fueron gestando La Ilustración. Periódico Universal (1849-1857), el diario Las Novedades fundado en 1850, la Biblioteca Universal diaria y colecciones de novelas como El Eco de los folletines. Su imprenta se llenó de grabados de importación y en sus páginas entraron a raudales aires europeos, desde la Exposición Universal de Londres (1851) a la Guerra de Oriente cuyos Anales fueron el plato fuerte informativo entre 1854 y 1856 . De este modo, aprovechando la expansión económica promovida por el moderantismo político que él combatía, llegó a convertirse en el primer editor del realismo periodístico en España, mientras se frustraban entre las dos aguas - pintorescas y universales - otras estimables publicaciones de aquellos años, como El Fénix o La Semana. El detalle minucioso de este proceso escapa a las posibilidades de nuestra exploración, por lo que nos limitaremos a esbozar las que nos parecen sus líneas maestras y resaltar algunas de sus figuras más señaladas.

Las «Revistas» de actualidad en el pintoresquismo romántico (1843-1849)

El Laberinto incluyó una sección de «Sucesos contemporáneos» y una «Revista de la quincena» de predominio noticiero sin grabados, con especial atención al teatro, cuya firma compartieron Enrique Gil y Carrasco, Antonio Ferrer del Río, Juan Pérez Calvo y Antonio Flores. Este último, la personalidad más destacada del periódico, dejó huellas de escepticismo al constatar el retroceso de la revolución liberal tras la desamortización, al tiempo que defendía la secularización de la literatura ante el ataque de los púlpitos contra Los misterios de París que él mismo acababa de traducir: «Nosotros creemos que los predicadores pueden y deben ilustrar a su auditorio sobre la elección de libros, más o menos a propósito al pasto espiritual, pero el análisis de obras 
determinadas no pertenece seguramente a los misioneros; ni mucho menos en los días de cuaresma para los que tiene la Iglesia sus puntos determinados». (LAB, 1845: II, 126). Aunque El Laberinto se había propuesto enriquecer su parte informativa de la actualidad con imágenes de «los sucesos de más bulto» que ocurrieran en España ( $L A B, 1843$ : I, 27) distó mucho de alcanzar resultados significativos en este aspecto (Riego: 2001a: 179).

Durante cuatro años, un periódico periférico como El Fénix escenificó el esfuerzo infructuoso para deslindar formalmente lo "pintoresco» y lo «universal». En 1844 se inició como «Semanario valenciano» con «crónicas» semanales o quincenales, habitualmente firmadas por Miquel y Roca, impregnadas de un acusado color local. En octubre de 1845 se transformaba en «Periódico Universal» y el cronista, inspirado en L'Illustration francesa, introdujo el epígrafe de "Correo de Valencia» ensayando alambicadas alegorías literarias de componente narrativo-costumbrista entreveradas con noticias domésticas que fueron ganando progresiva presencia, sin renunciar a ciertas galas de estilo. En realidad, la imaginación de Miquel y Roca no tenía medios para abrirse a la actualidad exterior. Se conformaba con ironizar hiperbólicamente sobre el alto grado de «civilización» de sus lectores y con la posibilidad de comparar sus costumbres con las de países tan ignorados como la China, el Japón, la Tartaria, el Afganistán o la Laponia (FÉN., 40. 2. ${ }^{\circ}$ : 190). De ahí que muchos de sus «correos» se redujeran a un rosario de noticias, cuya máxima cota «universal» fueron las notas necrológicas de Jaime Balmes y de Chateaubriand (FÉN., 146. 4: 400). Pese a su carácter literario, las alusiones de El Fénix a asuntos de actualidad pudieron alertar a los censores, según parece insinuar un ambiguo «correo-crónica», firmado por la indescifrable sigla P.E.D.M.E.T.: «Terrible cosa es, en verdad, la censura, y si no fuera por ese temorcillo que nos asalta, cuántas cosas haríamos que dejamos de hacer... ¡Cuántas y cuántas!!!!» (FÉN, 73. 1847: 3. $\left.{ }^{\circ}, 247\right)$

Pero fue en El Siglo Pintoresco, impulsado por el grabador Vicente Castelló, donde mejor se definió la «revista» de actualidad «universal» como el espacio destinado a desarrollar la imaginería informativa fijando los grandes sucesos de la época y neutralizando el «vértigo del tiempo» mediante textos escritos que ampliaban su alcance combinados con retratos de personajes, escenas, vistas de edificios y objetos materiales, imágenes cuya manufactura de origen quedaba garantizada bajo la difícil promesa de no reciclar jamás grabados de publicaciones españolas ni extranjeras (ESP: 1845: 2-3). La innovación gráfica se ponía al servicio del conservadurismo romántico de modo que, durante la consolidación del sistema liberal, el aura tecnológica del grabado en madera como instrumento informativo daba pie a los editores para 
proclamar su voluntad de progreso por encima de sus posiciones políticas. A la innovación se confiaba el beneficio a corto plazo, determinante para sostener negocios editoriales basados en suscripciones anticipadas y en el azaroso crédito de impresores ya establecidos. Por otra parte, como ha sugerido Bernardo Riego (2001a: 108), práctica artística y soporte ideológico se solapaban en la apariencia informativa de los grabados. No parece aventurado suponer que los incipientes medios de masas promovidos por la burguesía trataban de universalizar un imaginario sectorial de clase basado en la calidad estética de sus imágenes y en la selección literaria de los asuntos, en detrimento de los rudimentarios tacos de boj de los impresos populares que, no obstante, resistieron durante mucho tiempo ilustrando pliegos vulgares de relatos y cantares con destino a consumidores de menor capacidad adquisitiva, en la frontera con la vieja cultura de tradición oral.

Bajo dirección literaria del tradicionalista Navarro Villoslada, las revistas mensuales de El Siglo Pintoresco — por lo general, anónimas- aparecieron divididas en dos partes: «España»y «Extranjero». La segunda desapareció pronto y la actualidad política nacional quedaba explícitamente excluida para evitar el «proceloso mar» de las contiendas y disensiones civiles (ESP, 1845: 117). Fernández de los Ríos, su sucesor en el puesto, reconocía por imperativo práctico que la sección no podía alcanzar la universalidad pretendida: «Sabemos bien que el espacio de que podemos disponer y el carácter mensual de nuestras revistas, se opone a que sean una reseña extensa de todos los sucesos de Europa». Por ello se conformaba con que constituyeran «una especie de anuario curioso» donde registrar «con la pluma y el lápiz» todo cuanto fuera merecedor de «consignarse en los anales de una colección destinada a gentes de conocida cultura» (ESP, 1847: 2-3). La sección pasó a denominarse «Revista mensual»y, aunque en ella prevalecieron contenidos noticieros, el progresismo del firmante no perdió ocasión de transmitir soterrados mensajes de alarma ante el «descontento público y hasta desesperación» que producía el «complicado laberinto» de la política nacional y de las «tormentas que rugen sobre nuestra infeliz España» (ESP, 1847: 21). Rozando campos ajenos al de un periódico «ameno e instructivo» —exento de depositar las elevadas fianzas exigidas por los gobiernos a las publicaciones con derecho a intervenir en debates políticos- el revistero recurría al pesimismo retórico para conmover al lector ante el riesgo de una segunda guerra civil: «Postrado nuestro espíritu, muerto nuestro entusiasmo, desvirtuadas nuestras creencias y secos nuestros ojos, aguardamos los sucesos, con la impasibilidad con que entra el enfermo, cuyos padecimientos han agotado su sensibilidad y sus esperanzas...» $(E S P, 1847: 71)$. 
Por excepción en su larga trayectoria, el Semanario Pintoresco Español, durante su coincidencia empresarial con El Siglo Pintoresco - primer semestre de 1846 - sostuvo una «Revista de la Semana» sin firma, pero atribuible a Navarro Villoslada, cuyas veinticuatro entregas contenían noticias musicales, teatrales, literarias, ateneístas y liceístas, religiosas, hípicas, de reformas urbanas, salones y actividad palaciega. Su carácter semanal validaba su función informativa, y su concepto unitario del discurso admitía intromisiones subjetivas del autor de modo que el revistero podía mostrarse sensible a los contraste sociales - la huelga de los aguadores de Madrid mientras las «clases elevadas» celebraban la entrada de año en Palacio (SPE, 1846: 16)—, o al presumible estremecimiento del público teatral, ya instalado en el «justo medio», recordando los días en que «resonaba el eco terrible de los sangrientos y espantables engendros de la exagerada escuela romántica». (SPE: 1846: 47). También esta «Revista» se vio afectada por el cambio de empresa a mitad de año (Rubio, 1995: 68-71; 91-92). Con el argumento de que no se acomodaba a las «dimensiones y naturaleza del periódico», Fernández de los Ríos la sustituyó de inmediato por una «Crónica» con noticias intencionadamente seleccionadas, expuestas en «párrafos sueltos», ilustradas con grabados de discutible actualidad, algunos reciclados de El Siglo Pintoresco: véanse «Carrera de caballos en la Real Casa de Campo», publicado el 10 de mayo en SPE: 1846: 152, insertado un año antes en ESP: 1845: 47; o «El delirio del pintor», en marzo en ESP:1846: 70, y en SPE: 1846: 296 (13 de septiembre). La relación entre texto y grabados de actualidad fue particularmente intensa en el otoño de 1846 con motivo de las dobles bodas reales de Isabel II y de la Infanta María Luisa, objeto de gran despliegue informativo en Semanario Pintoresco, analizado en su dimensión de reportaje pionero por Riego (2001a: 173-175). La empresa prefirió las columnas del Semanario porque la mayor frecuencia de su aparición permitía insertar el relato a medida que se iban celebrando los festejos (SPE: 1846: 320). Entre el 10 de octubre y el 15 de noviembre se ofrecieron siete extensas entregas de texto sin firma, ilustradas con treinta y cuatro xilografías de varia dimensión — retratos, escenas, actos públicos, viñetas ornamentales-, firmadas por los dibujantes Joaquín Tomé, Joaquín Sierra y Carlos Múgica, grabadas en su mayor parte por Castelló y alguna por Félix Batanero, bajo el epígrafe común de «Sucesos contemporáneos». Sin embargo Fernández de los Ríos, diversificando la función de los periódicos que dirigía, reservó su «Revista del mes de octubre» en El Siglo Pintoresco para poner un contrapunto crítico personal acerca de su papel como descriptor mediático de los fingimientos de alegría y apariencias de felicidad que tales fastos producían, expresando su fatigado escepticismo ante la teatralidad de 
tantas comitivas, funciones de iglesia, danzas de vagos y de mujeres sin ocupación, «arcos triunfales, templetes de lienzo, fachadas figuradas, perspectivas provisionales» que lo mismo servían «para celebrar la coronación de un rey que la noticia de una victoria, lo mismo en un sistema de gobierno que en otro» (ESP, 1846: 236).

En general, las «revistas» de este periodo se acomodaban a esquemas de contenido destinados a perdurar hasta la época de las grandes ilustraciones: secuencia de iniciación; meteorología estacional, a veces adornada con ribetes líricos y proverbiales; fastos del calendario; exposición selectiva de hechos, con digresiones anecdóticas, excursos críticos y frecuentes guiños de complicidad al lector; noticias escénicas, aunque hubiera aparte «Revista de Teatro», y novedades bibliográficas.

\section{Hacia el realismo. La primera Ilustración (1849-1857)}

1849 fue clave para el asentamiento de los periódicos universales en España con la aparición en Madrid de La Ilustración (n. ${ }^{\circ}$ 1: 3 de marzo) y de La Semana, que aún mantenía el sello de "pintoresco» en su cabecera $\left(\mathrm{n}^{\circ} .1: 5\right.$ de noviembre). Respecto a la actualidad ambas adoptaron inicialmente la fórmula de L'Illustration — «Histoire de la semaine» y «Courrier de Paris»—, distribuyendo su información del movimiento político español y europeo en dos secciones fijas: «Historia de la Semana», anónima, de cariz noticiero y «Revista de Madrid», firmada, con un tratamiento más personal y subjetivo. Fernández de los Ríos declaraba su voluntad de registrar en la primera de dichas secciones acontecimientos debatidos en la prensa y en «la conversación general» durante la semana anterior, «con la templanza, el reposo y la sangre fría de espectadores cómodamente colocados». (ILU, 1849: 1). Por su acarreo de fuentes ajenas, la «Historia de la Semana» era la única sección cuya propiedad intelectual no se reservaba la empresa del periódico (ILU, 1849: 208). Esta parte noticiera sufrió cambios y reajustes bajo otras denominaciones: «Panorama universal» (1849), «Sucesos contemporáneos» (1849), «Sucesos de actualidad» (1851-1857), «Revista Universal» (1853-1857) o «Acontecimientos de actualidad» (1855). En 1853 se insertó con periodicidad mensual una «Crónica matritense» de tendencia objetivista en la que se adivina la mano del director. La información teatral, musical y literaria contó regularmente con «revistas» propias de reseñas críticas.

La aportación literaria más llamativa de La Ilustración fue la incorporación de Ramón de Navarrete (1818-1897) como redactor de la «Revista de Madrid» cuyo género ya venía practicando en el folletín de El Heraldo, encubriendo su nombre con ${ }^{* * *}$. Aunque sin sostener con exactitud la anunciada 
periodicidad quincenal de sus artículos, el polifacético escritor - periodista, dramaturgo, narrador, cronista de salones (Rubio: 2008) y colaborador de El Siglo Pintoresco (Rodríguez Sebastián, 2012) - alcanzó en las páginas de La Ilustración su madurez como revistero. En 1852 y 1853 la sección se eclipsó, pero volvió a reaparecer en 1854, firmada con el seudónimo de Leporello. El modelo más repetido en sus artículos es el lineal-discursivo, con un íncipit generalizador seguido del cuerpo del artículo, con inserción dosificada de breves núcleos en estilo directo que concretan el hilo argumental, a manera de anécdotas probatorias, dando ameno cuerpo a breves escenas costumbristas. Ensayó también media docena de «revistas» en forma epistolar con enunciado en segunda persona, entre las que destacan la dirigida a Carolina Coronado, contestada por ésta a vuelta de correo, y una memorable a la Condesa de Montijo «reina de la moda y el buen tono» (ILU, 1850: 379). Otra dirigida a Manuel Silvela desvelaba su seudónimo Velisla como si se tratara de una máscara carnavalesca (ILU, 1851: 2 y 17-18). En la última, dirigida al director del periódico, explicaba la imposibilidad de continuar sus artículos al entrar Madrid en su anual «modorra veraniega» (ILU, 1854: 201-202). Con este mismo tópico anual, compuso en 1849 una «revista» festiva en octosílabo arromanzado despidiéndose temporalmente de su público femenino: «Amadas lectoras mías; / hoy mis Revistas suspendo/ hasta que venga setiembre/ con sus lluvias y su fresco. / Porque ¿de qué puedo hablaros/ en estos meses funestos, / cuando cerrados están/ salones y coliseos; / cuando escapa todo el mundo / hasta Fuencarral lo menos; / cuando no hay bodas ni intrigas,/ ni saraos, ni aun conciertos?...» (ILU: 1849: 135). Es habitual la percepción de un Navarrete al servicio de las damas, con sus detalladas referencias a los salones y a la vida elegante. Experto en el arte de la insinuación, sus reticencias intrigantes y silencios sedicentemente respetuosos se confundían en la ambigüedad con la que pretendía incrementar la curiosidad y dar pábulo a la rumorología (ILU: 1851: 121). Por propia naturaleza, sus «revistas» rezumaban espíritu de distinción, obligadas a complacer a la alta sociedad cortesana. Pero, al mismo tiempo, el progresismo latente en La Ilustración caldeaba efusiones populistas que abonaban el paternalismo con que el escritor construía sus abstracciones interclasistas. "¡Qué diferencia [...] entre el afán con que el pueblo apura hasta lo último los goces, y el desvío que hacia estos sienten o afectan las clases elevadas! [...] ¡Felices, mil veces felices, los que corren, bailan y chillan por las calles!» (ILU: 1851: 57). La lisonja populista ¿expresaba las contradicciones del periódico, cuya supervivencia empresarial se debatía entre la voluntad instructiva y la necesidad de contar con una suscripción solvente que solo podían garantizar los sectores más acomodados? 
El repertorio retórico del revistero Navarrete era variadísimo: recurrencias sintácticas, rupturas de sistema, juegos de contrarios, amplificaciones y gradaciones, correlaciones anafóricas para vertebrar el ritmo del discurso, hábil manejo del clímax, comunicaciones, frases proverbiales, galicismos paródicos y mucha ironía a flor de piel. Como botón de muestra, véase la economía metonímica con que configura el tópico costumbrista del «amigo» — la simulada objetividad de la opinión ajena- para sugerir las jerarquías y estrecheces del «quiero y no puedo» en la buena sociedad madrileña: «El martes se verificó el primer baile en los salones de Villa-Hermosa que un amigo nos pintaba de una manera lacónica y expresiva, diciendo que había habido mucho paño, bastante algodón, y poca seda». (ILU, 1951: 57).

En La Semana, se hizo cargo de la «Revista de Madrid» el jurista gaditano José María de Antequera y Bobadilla (1819-1891), antiguo colaborador del Semanario Pintoresco (1842), que a su vez firmaba la «Revista teatral». Su labor estuvo marcada por cierta propensión divagadora para manejar expansivamente los habituales tópicos estacionales — «descarnado y macilento rostro» del invierno (SEM, I: 113), exaltación de los placeres domésticos de la NocheBuena, perturbaciones atmosféricas de cada marzo, veraneos que desertizaban la Corte o sensaciones crepusculares de un relamido eclecticismo: «Los días comienzan a acortar; el cielo se anubla y oscurece; pierde la atmósfera su diáfana transparencia; palidecen y se entibian los rayos de sol; despójanse los árboles de su vistoso follaje; acrece el frío, comienzan las lluvias; y con las últimas hojas de la flor del vergel, despójanse también de sus aéreos trajes las bellas hijas del Manzanares». (SEM, 1850: II, 353). Los esquemas de sus «revistas» no eran muy distintos a los de Navarrete, salvo en su menor intensidad expresiva. Dada la inmediatez periódica de ambos medios — La Ilustración salía los sábados; La Semana, los lunes)— no faltaron coincidencias temáticas, ni algún chispazo intertextual de Antequera, apostillando burlón los comentarios de Navarrete sobre el programa semanal de bailes y recepciones en los principales salones madrileños: «¿Quién es capaz de resistir a una vida tan monótona, tan triste, tan escasa de diversiones? [...] Porque al fin el hombre se ha hecho para bailar, como el pez para vivir en el agua» (SEM: I, 1849: 98). Antequera partía de una secuencia inicial de situación espaciotemporal que anticipaba el núcleo o núcleos informativos, que iban a merecer su atención. En su desarrollo recurría a insertar anécdotas, al diálogo y a la segunda persona epistolar (SEM, II, 193-194). En torno al motivo existencial del viaje, ensayaba fáciles disyunciones isotópicas para resaltar contrastes sociales: «Unos surcan osados la vasta extensión de los mares, mientras otros atraviesan en tierra las cordilleras y los llanos: unos marchan con la velocidad del rayo a 
impulso de la poderosa locomotiva, mientras otros se limitan al trote de un caballo francés, o de una mula de Castilla: unos se columpian muellemente en el coche, mientras los otros se traquetean bien a su pesar en el carro, y unos montan en prosaica cabalgadura, mientras otros se contentan con medir las distancias a pie. [...] Unos viajan por el globo terráqueo, otros viajan por los libros, y otros muchos por los espacios imaginarios». (SEM: II: 162)

Por excepción, el 24-6-1850, Antequera firmó una «revista» gráfica de varia lección — «Salones. Teatros. Modas. Costumbres»—a doble página, con 18 viñetas xilográficas (dibujos de Fernando Miranda y Vicente Urrabieta, grabados por José Gaspar, Ildefonso Cibera y José Benedicto), donde breves textos - casi todos dialogados - servían de pie explicativo a las ilustraciones. Uno de ellos convertía al mesoneriano Don Homobono Quiñones en prepotente propietario de Chinchón con inclinaciones duelistas (SEM, II: 114-115).

Justamente la propensión de Antequera a incidir en los aspectos morales de algunas noticias se hacía patente en su reiterada condena de los desafíos, remedando a infranqueable distancia la gravedad de Fígaro: «El siglo es duelista, y es forzoso que nosotros vivamos con el siglo. Los hombres no dilucidan ya las cuestiones en el reducido espacio de un salón; han menester otro terreno: el campo es de imprescindible necesidad para discutir los asuntos importantes: entonces no se cruzan nuevos argumentos; pero se cruzan balas: y cuando una de ellas ha tocado el cuerpo del otro, se dice que los hombres quedan con honor, y la sociedad satisfecha. Tal es la doctrina corriente de la sociedad actual en materia de discusiones: tal es la filosofía del presente siglo. La mejor razón, la bala». (SEM, 1850, I: 210). Más incisiva es su macabra alegoría de las miserias del hospicio madrileño de las que responsabilizaba a una «sociedad» incapaz de encontrar recursos «para rescatar de las garras de la muerte un sin número de víctimas inocentes. La inclusa es la barca de Caronte, por donde transitan las almas desde el uno al otro mundo. Ello no habrá contribuido mucho en favor de los vivos; pero ha aumentado considerablemente el coro de los ángeles del Señor» (SEM, I: 337). El desglose de asuntos es muy amplio: animación social, bailes y saraos, caridad y beneficiencia, academias, fiestas populares, caminos de hierro —el más alto índice del progreso tecnológico- o el contraste entre la tranquilidad española y la agitación política europea (abril de 1849). La satisfacción de Antequera ante las reformas urbanas que habían cambiado Madrid en el decenio de 1840, disipa en él todo vestigio nostálgico del ubi sunt dando la prioridad a los espacios «hallados» sobre los «perdidos».

El cuadro del proceso evolutivo que conduce a la madura crónica literaria del fin de siglo, no quedaría completo sin mencionar la aportación de Antonio 
Flores en «Un año en Madrid», que había tenido precedente en otra serie suya de siete entregas en El Laberinto, titulada «Una semana en Madrid» (184344) (Rubio, 1977: I: 60-66). Se trata de un ciclo de doce artículos, ilustrados por Urrabieta y Calixto Ortega, aparecidos en la publicación «pintoresca» de Mellado Museo de las Familias (VII, 1849), cuya originalidad radicaba en configurar una visión de situaciones mensuales previsibles con sujeción al calendario meteorológico y festivo, extrayendo lo genérico sustancial de los tópicos temporales fijos que los revisteros de la actualidad reiteraban, año tras año. Respetuoso con la realidad, prolijo, discursivo y reflexivo, Flores encerraba lo permanente de la vida madrileña, mes a mes, en unas tres páginas a doble columna. Mediante un discurso verosímil, fruto de una dilatada experiencia de sutil observación, el autor abordaba el contraste entre lo estable y lo mudable de los hábitos sociales urbanos con los recursos costumbristas, inventando una crónica a la inversa que, junto a las «revistas» de Ramón de Navarrete, podría ser punto de arranque de la causerie a la española. En un país donde no se conjugaba el presente del verbo hacer — reflexionaba el escritor ilicitano-y en una Europa revuelta y agitada por descubrir verdades dudosas, valía la pena emprender un viaje por el Madrid más próximo, por aquello de que no era bueno dejar lo propio para buscar lo ajeno desconocido. Principio experimental de la observación realista (MdlF, 1849: 21).

\section{Nemesio Fernández cuesta en el museo universal (1857-1864)}

El paradigma de la «Revista» de actualidad se asentó y regularizo como esencialmente noticiero en El Museo Universal, periódico artístico, científico y literario cuya «Introducción», firmada por José Puiggarí (1821-1903), declaraba prioritario el carácter generalista que requería una «época de universal propaganda» destinada a superar la inanidad de tantas «publicaciones llamadas literarias y pintorescas» hundidas «sin dejar rastro». (MUS, 1957: 1-2). Fue primero «Revista de la quincena», entre 1857 y 1859, con ilustraciones de Carlos Ribera, Francisco Ortego o Federico Ruiz, en la última página, que correspondía a la cara del pliego donde se imprimían los grabados. Ganó relevancia a partir de 1860 como «Revista de la semana» en primera plana, ya sin ilustraciones de referencia en el espacio de la sección. La forjó, a lo largo de sus primeros ocho años, el periodista republicano Nemesio Fernández Cuesta (1818-1893) — próximo a Salmerón y a Prim-, director de la editorial de José Gaspar y Fernando Roig, redactor de La Discusión, propietario de Las Novedades desde 1857 y autor del folleto Vindicación de la democracia española (1858). Objetivo y prolijo, impuso un apretado resumen de noticias españolas y extranjeras que, durante los ocho años que estuvo al frente de $E l$ 
Museo, evolucionó desde la enunciación lineal estrictamente noticiera, con escasa presencia de acontecimientos políticos, hasta «revistas» con una forma expositiva más flexible, que admitían la divagación irónica, el escolio, la interpretación y la explicación instructiva sobre toda clase de asuntos, incluidos los sociológicos y económicos. Fascinado por los avances intelectuales y morales de su tiempo, pese a oscilaciones políticas, disturbios y revueltas, Fernández Cuesta, optimista en años de expansión, veía a su periódico no sólo como espejo registrador del progreso sino también como parte del progreso mismo (MUS, 1859: 1-2). En 1859 abordó la información de Guerra de Italia - Montebello, Magenta, Solferino- no sin causticidad comparatista: «Mientras fuera de España se agitan las más importantes cuestiones para la humanidad, nuestra juventud florida y nuestros hombres graves toman a pechos una reforma capital..., la reforma del sombrero» (MUS: 1859:71-72). Pero cuando llegó el contagio del belicismo, su «revista» fue fiel testigo de la campaña de África, aprobándola, alentándola y registrando el fervor mediático que suscitaba, respondiendo a la convicción del liberalismo democrático que veía en la expansión económica en Marruecos una garantía del progreso y de la ilustración nacional. (Riego, 2001b: 568). La perspectiva de que se consolidara la ocupación de Tetuán era recibida con complacencia por el revistero quien se permitía recomendar una política colonizadora respetuosa con religión, haciendas y costumbres de árabes y judíos que, supuestamente «disgustados del gobierno del sultán», se someterían gustosos a un dominio español tolerante (MUS, 1861: 209). Por las mismas fechas (7 de julio), reprobaba el desesperado levantamiento campesino de Rafael Pérez del Álamo en la provincia de Granada, destinado al fracaso porque no se entendía «cómo Loja pudo ser elegida por centro de una sublevación que durase más de una semana». Los tics patrióticos renacieron a propósito de la anexión de Santo Domingo (1861) — cuyas primeras noticias llegaron a El Museo un mes después de haberse producido ( 21 de abril) — y de las operaciones militares expansionistas en México (1862). Aparte de la tópica exaltación de españolidad, la convicción democrática del revistero lo impulsaba a pedir la libertad y demás derechos civiles que se habían de respetar en Santo Domingo, para las islas de Cuba y Puerto Rico con el fin de neutralizar «las tentativas del filibusterismo» en las Antillas (MUS: 1861: 121). Respecto a la aventura mexicana de Prim y al desembarco español en Veracruz, se mostró a tono con la sorna popular de los invadidos - que menospreciaban con cantos burlescos la llegada de «los gachupines con dos guitarras y tres violines»-mediante una concatenación alegórica que seguía el pie forzado del motivo orquestal para describir connotativamente el aumento de efectivos de la Armada española: 
«cuando observaron que a las guitarras y violines sucedían las flautas, a las flautas los oboes, a estos los serpentones y todos los instrumentos de bronce, dijeron que no les gustaba la música, y tomaron el partido de irse cantando bajito». (MUS, 1862 25).

Mirando por los intereses del suscriptor burgués del semanario, Fernández Cuesta, entre noticia y noticia, ejerció una paciente labor didáctica en materia de economía política, intentando vulgarizar con claridad conceptos crediticios y financieros en apoyo de la iniciativa privada, intentando conciliar principios de libre cambio con una sana moral social, partiendo de los casos prácticos que proporcionaban las frecuentes quiebras de fondos y las especulaciones bursátiles más escandalosas que precedieron a la crisis de 1866 . Para él, la prensa estaba llamada a ejercer una función educativa en el orden financiero, como exponía en febrero de 1862, bajo el pánico que produjo en la Bolsa la quiebra de la casa O'Shea (MUS, 1862: 33). Impulsos regeneracionistas lo llevaron a condenar repetidamente el juego y las loterías fomentadas nocivamente por los gobiernos, porque «cuando la renta de loterías sube, es señal de que los hábitos de trabajo y de economía disminuyen» (MUS: 1861: 393). Censuraba, sin renunciar a su habitual ironía, que quienes defendían con uñas y dientes sus ahorros fuesen capaces de dilapidar parte de ellos en loterías con solo un 1/55000 de posibilidades de obtener premio: «Que los imponentes en las cajas de ahorros acudan presurosos a sacar su dinero a la menor señal de peligro, poniendo en peligro real sus caudales por la misma precipitación con que se acude a recogerlos, y que entre tanto se arrojen por la ventana en un mes cerca de 20 millones de reales [...] en el ramo de loterías, es para nosotros una cosa deplorable. Desearíamos que se encontrase una combinación lotérica que hiciese quebrar este banco: ¡vaya si lo desearíamos! ¡Si hay alguno que cree haberla inventado, que acuda y jugaremos!» (MUS, 1862: 41). En otro campo, el humanitarismo del revistero brillaba enérgico contra la costumbre penitenciaria de asilar en las cárceles a hijos de presos: «Las cárceles no son casa de corrección, en el estado en que hoy se encuentran; por el contrario son escuelas del delito; centros de corrupción y de contagio moral; lugares infestados por una enfermedad epidémica que deteriora la salud del alma cuando no la mata. Llevar la niñez a estos lugares, hacerle respirar su atmósfera apestada, es simplemente envenenarla». (MUS, 1863: 184)

Acabado el gobierno largo de la Unión Nacional, con la caída de O’Donnell (1863) no mermó la firmeza de sus opiniones, acaso más expuestas al poderoso lápiz rojo del fiscal de imprenta: «En El MUSEO no sucede lo que en otras muchas partes, donde del dicho al hecho hay gran trecho: aquí el dicho es el 
hecho, y el hecho se confunde generalmente con el dicho». (MUS, 1864: 81). En 1864, acentuó su defensa de la economía liberal contra el intervencionismo estatal que entraba en competencia con las sociedades de crédito al elevar los intereses de la Caja General de Depósitos (MUS: 1864:409); contra el monopolio estatal de tabacos (MUS, 1864: 121) o contra la centralización administrativa (MUS, 1864: 361). En sus últimas revistas se deja ver algún brote de exasperación: «¿Habrá algún español a quien no se le haya caído la cara más de una docena de veces, avergonzado ante el contraste que en muchos puntos forma nuestra patria con las demás naciones? Pues caten ustedes que si cada vez que uno ve ciertas cosas se le cae la cara, no una docena, sino diez, necesitamos para reponer las que se nos vayan cayendo». (MUS, 1864: 257)

Basten estas mínimas calas para apreciar que con Fernández Cuesta en la dirección, la «Revista de la Semana» de El Museo Universal sobrepasó los límites de intencionalidad política propia de un periódico ilustrado de ciencias, literatura artes y conocimientos útiles. Discrepancias con el criterio de los editores lo llevaron a ser sustituido por periodistas más acomodaticios.

\section{Pérez Galdós Revistero en 1865}

Por las mismas fechas Benito Pérez Galdós hacía su aprendizaje como revistero semanal en La Nación —diario progresista inspirado por Pascual Madoz- y en la Revista del Movimiento intelectual de Europa. En el primero, por su carácter de periódico político, tuvo licencia para ironizar sobre sucesos de actualidad. En cambio su cometido en la Revista... se reducía a teatros, ópera y libros, sin margen para el comentario político. De la riqueza genérica, los valores literarios y el carácter ideológico de la aportación de Galdós a estas «revistas» se han ocupado cumplidamente Pérez Vidal (1987), Hoar (1968), Shoemaker (1972) y otros, por lo que me limitaré a ensayar algunas calas comparativas en su actividad revistera de 1865-1866 en relación con las «Revistas de la semana» en El Museo Universal durante el mismo periodo.

Mientras el joven Galdós, simpatizante de Prim y de los conspiradores demócratas, trabajaba intensamente como redactor de La Nación, en el Museo Universal firmaron sucesivamente la Revista de la semana dos periodistas de ideas conservadoras: León Galindo y de Vera, oscuro jurista destinado a preceder al escritor canario en su asiento de la Real Academia, y Gustavo Adolfo Bécquer, de cuyas Obras había de ser Galdós comprensivo receptor crítico. Galindo, en 1865, reservaba a cuestiones españolas una mínima parte de sus revistas. En general sus textos eran bastante anodinos y para paliarlo solía concluirlos con algún chascarrillo o chiste blanco de escaso efecto. La violenta Noche de San Daniel apenas modificó su esquema. Se limitó a 
calificar de «fúnebre» su revista del 16 de abril donde la mínima alusión a los «sucesos» quedaba contrarrestada por la imagen de normalidad con que los fieles visitaban los templos, atraídos por «los terribles y dolorosos misterios de la redención del hombre y de la muerte del Señor». Completaba el cuadro luctuoso la necrológica del ministro de Fomento, Antonio Alcalá Galiano, muerto repentinamente en una reunión del Consejo donde se discutían los hechos. El revistero no aclaraba sus últimas palabras — «El 10 de marzo, el 10 de marzo»— limitándose a comentar que «no tenían relación alguna con lo que se discutía». (MUS, 1865: 121). En realidad, Alcalá Galiano asociaba con lucidez agónica la represión gubernamental de aquellos días con la carga cruenta de las tropas realistas en 1820 cuando la multitud indefensa celebraba en Cádiz el restablecimiento de la Constitución, que él mismo había recordado en sus memorias.

Galdós en su «Revista de la semana» del 23 de abril (Shoemaker, 1972: 56-58) iba mucho más lejos al asociar «la sangre derramada» de los estudiantes con la degollación de los inocentes en «el vestíbulo del templo de Cristo», acusando al Gobierno de haberse excedido en sus funciones, aplicando a «una travesura estudiantil [...] el suave correctivo de las balas. Y esto en Semana Santa, es decir, en las barbas de Jesucristo». El revistero describía con tintes esperpénticos la insensibilidad del pueblo madrileño entregado a la anual distracción de recorrer iglesias bajo la lluvia, y veía la procesión del Viernes Santo como «un conjunto híbrido de fanatismo y descaro», mezcla del drama terrorífico y del sainetón abigarrado» protagonizado por «las turbas sacristanescas» que se le antojaban movidas por un «instinto sangriento de diversión» ajeno a un entusiasmo religioso destinado a excitar dignamente la fe. Con similar severidad se refería a Alcalá Galiano disociando con sarcasmo lo «divino» del entierro de Cristo y lo «ministerial» del sepelio del ministro: «Todo el boato desplegado en la calle de Fuencarral demuestra la clase a que pertenecía el finado; el estrépito de los tambores y las descargas de fusilería suple el sentimiento unánime del pueblo, que es el mejor acompañamiento de los que mueren después de merecer bien de la patria. En el entierro de Galiano no ha habido nada de esto. Boato, lujo, y nada más; es decir, lo que merecía».

\section{El cruce de Galdós y Bécquer en 1866}

La muerte del duque de Rivas fue el primer motivo de coincidencia periodística entre Galdós (La Nación, 2-7-1865) y Bécquer, cuando éste no había accedido todavía a la redacción de El Museo Universal. Mientras el joven periodista canario ponderaba la modestia con que Saavedra había bajado a la 
tumba rehusando las pompas fúnebres, el sevillano trazaba un brillante cuadro de la existencia del difunto, egregio varón, poeta y soldado. Donde Galdós informaba sucintamente humanizando al muerto, Bécquer lo divinizaba con prosopopeya y extensa documentación bibliográfica (MUS, 1865: 210-211).

La «Revista de la semana» en el Museo Universal, aparecía los domingos, coincidiendo con la de Galdós en la edición literaria de La Nación, mientras que la Revista del Movimiento Intelectual de Europa, donde también colaboraba el escritor canario, salía los lunes. La mayor variedad de materias abarcables - política europea, española, vida social, cultural y teatral— correspondía a

CORRESPONDENCIAS ENTRE BÉCQUER Y GALDÓS EN SUS RESPECTIVAS «REVISTAS DE LA SEMANA» (1860)

\begin{tabular}{|c|c|c|}
\hline BÉCQUER & \multicolumn{2}{|c|}{ GALDÓS } \\
\hline $\begin{array}{l}\text { Museo Universal } \\
\text { (domingos) } \\
3 \text { columnas }\end{array}$ & $\begin{array}{l}\text { La Nación. Diario Progresista } \\
\text { (domingos) } \\
5 \text { columnas, folletín corrido }\end{array}$ & $\begin{array}{l}\text { Revista del movimiento Inte- } \\
\text { lectual de Europa (lunes) } \\
2 \text { columnas } \\
\end{array}$ \\
\hline $\begin{array}{c}7 \text { enero } \\
14 \text { enero } \\
21 \text { enero } \\
28 \text { enero } \\
4 \text { febrero } \\
11 \text { febrero } \\
18 \text { febrero } \\
25 \text { febrero } \\
4 \text { marzo } \\
11 \text { marzo } \\
18 \text { marzo } \\
25 \text { marzo } \\
1 \text { abril } \\
8 \text { abril } \\
15 \text { abril } \\
22 \text { abril } \\
29 \text { abril } \\
6 \text { mayo } \\
13 \text { mayo } \\
20 \text { mayo } \\
27 \text { mayo } \\
3 \text { junio } \\
10 \text { junio } \\
17 \text { junio } \\
24 \text { junio } \\
1 \text { julio } \\
8 \text { julio } \\
15 \text { julio } \\
22 \text { julio } \\
29 \text { julio } \\
5 \text { agosto } \\
12 \text { agosto }\end{array}$ & $\begin{array}{l}18 \text { febrero } \\
11 \text { marzo } \\
18 \text { marzo* } \\
25 \text { marzo* } \\
1 \text { abril } \\
8 \text { abril } \\
15 \text { abril* } \\
\\
6 \text { mayo } \\
13 \text { mayo } \\
20 \text { mayo } \\
3 \text { junio } \\
10 \text { junio } \\
17 \text { junio }\end{array}$ & $\begin{array}{c}8 \text { enero } \\
15 \text { enero } \\
22 \text { enero } \\
29 \text { enero } \\
5 \text { febrero } \\
12 \text { febrero } \\
19 \text { febrero } \\
26 \text { febrero } \\
5 \text { marzo } \\
12 \text { marzo } \\
19 \text { marzo } \\
26 \text { marzo } \\
2 \text { abril } \\
9 \text { abril } \\
16 \text { abril } \\
23 \text { abril } \\
30 \text { abril } \\
7 \text { mayo } \\
14 \text { mayo } \\
21 \text { mayo } \\
28 \text { mayo }\end{array}$ \\
\hline 32 revistas & 13 revistas & 21 revistas \\
\hline
\end{tabular}

*Revistas monográficas sobre actualidad bibliográfica y espectáculos teatrales. 
La Nación, como diario de partido pero también por ello estaba más sujeto a los efectos de la censura. Desde el 7 de enero al 12 de agosto, Bécquer firmó en El Museo Universal treinta y dos «Revistas de la Semana». La atención de Galdós a la actualidad se extendía a otras secciones de música y teatro, por lo que sus «revistas de la semana» propiamente dichas, como puede verse en la tabla anterior, tuvieron intermitencias, - a las que se sumaron dos suspensiones gubernativas de La Nación y la interrupción temporal del suplemento de Las Novedades (28 de mayo) donde el joven escritor asumía un compromiso de originalidad algo menos exigente que el de sus trabajos en el diario de Madoz, recomponiendo a veces en sus páginas de 1866 fragmentos e ideas de algunos textos ya publicados antes en La Nación (Hoar, 1968: 60-61).

Tras las elecciones del 27 de diciembre de 1865, ambos revisteros tuvieron difícil el comentar la intentona progresista impulsada por Prim en Villarejo de Salvanés el 2 de enero siguiente. O’Donnell disolvió los partidos políticos y se mostró enérgico con los implicados entre los que hubo varios fusilamientos. La Nación fue suspendida y Bécquer en el Museo Universal (7 de enero) anteponía la actualidad extranjera a la española como correspondía a un semanario «ajeno en un todo a las luchas y las pasiones políticas» (MUS, 1866: 2). También Galdós sufría las mismas limitaciones, pero era más incisivo al deplorar que el carácter literario de la Revista del Movimiento Intelectual..., le vedara «explotar el filón» de lo que consideraba «parte rica» de la actualidad — «política nueva, palpitante, candente»— debiendo ceñirse a la «parte estéril» —ciencias, artes, espectáculos. (Hoar, 1968: 119 y 190). Como redactor de La Nación había perdido la libertad de expresión, mientras que Bécquer veía la situación como una imprevista perturbación del orden legal consagrado por las urnas, que ponía en peligro «el desenvolvimiento de tantos intereses, y la realización de tantas esperanzas». El revistero sevillano se entregaba a un optimismo metódico convencido de que el país despertaba poco a poco de su letargo luchando entre «el espíritu de actividad y vida y el temor que engendran las preocupaciones de la doble crisis política y financiera». (MUS: 1866: 2). ¿A qué sector social dirigía estos mensajes de confianza? A partir de los proverbios y lugares comunes del habla, frecuentes en sus «revistas», M. ${ }^{\mathrm{e}}$ Linda Ortega ha apreciado el voluntario sometimiento del escritor «a la voz común, renunciando a cualquier originalidad estilística y empleando los estereotipos y clichés del hombre de la calle». Así Bécquer habría hecho concesiones en su estatuto de autor, adoptando la vulgaridad «de una escritura que se asemeja a una mercancía por su circulación y su modo de producción». (Ortega: 2003: 54-56). Tan sugestiva explicación no nos autoriza a suponer que el poeta-periodista cediera al mal gusto de las mayorías, sino más bien 
que vivía en alto grado las contradicciones entre su oficio de escribir a sueldo y el impulso creativo. Así permite sospecharlo el hecho de que, habiendo tildado de filfa informativa y comedia de enredo la crisis político-militar de enero y desdeñado el griterío plebeyo de los chicuelos vendedores callejeros de noticias, se identificara con los eruditos, sabios y artistas que, absortos «en la contemplación de las cosas grandes», no merecían ser distraídos por el motín que pasaba por debajo de sus ventanas: «Pocas son estas personas, pero para ellas escribimos», concluía rotundo (MUS, 1866: 9). Encerrado en un cierto conservadurismo vegetativo, «afligido por el espectáculo de las pequeñas miserias de la vida interior de los países», aunque poco propenso a analizar causas y efectos, Bécquer encontró pronto motivo compensatorio en la lejanas guerra del Pacífico que le permitían contribuir discretamente a la hoguera del patriotismo y tantear la eventualidad de una escritura épica sobre acontecimientos de actualidad (Ortega, 2003: 28). Sus descalificaciones del adversario tras el apresamiento de la goleta Covadonga y el suicidio del jefe de la escuadra, general Pareja, alcanzaron dimensiones tópicas en torno a la idea de que la honra nacional exigía «vengar con usura el agravio hecho a las armas españolas» (MUS, 1866: 25).

Las coincidencias entre las revistas semanales de Bécquer y Galdós en 1866 no pasan de diez si excluimos las que el segundo escribió con carácter monográfico. Entre los motivos folclórico-festivos del calendario — carnavales, cuaresma, semana santa... - hubo sincronías que permiten contrastar sus respectivos estilos de literatura periodística. Galdós afilaba sus primeras armas en el progresismo ideológico, mientras que a Bécquer parecía pesarle prematuramente el cansancio de una larga batalla. El canario dedicó al carnaval una fantasía de progenie larriana, tópico paseo por Madrid desde la Puerta del Sol hasta el Prado, recurriendo al motivo de la careta como segundo yo que simulaba alterar la conciencia del sujeto narrativo. Recuperada ésta, el autor concluía con una declaración racionalista de largo sentido: «aborrezco el carnaval y aborrezco las máscaras». El tránsito a la inmediata cuaresma lo esbozaba con desenfado, entre connotaciones profanas: un inmenso apagador sacristanesco mataba «las luces que ardían en los templos de Capellanes» y con ellas desaparecían tanto el culto al «buey gordo» como las «vírgenes» que mantenían «el sacro fuego de las pasiones matritenses». Por su parte, Bécquer se distanciaba nuevamente del ruido callejero sublimando con percepción paternalista la volubilidad de la «multitud», entregada al bullicio carnavalesco en olvido de recientes calamidades públicas: «El pueblo es como los niños: con la misma facilidad llora que se consuela, mostrando a veces juntas las lágrimas y la risa». (MUS, 1866: 49). En la concepción musical del poeta, la 
canción báquica carnavalesca — «atronadora sinfonía de los placeres mundanales»- dejaba paso solemne al «imponente acorde de Miserere» y al lúgubre estribillo del pulvis es. También Galdós concluía con el Memento homo... pero restando gravedad penitencial a las «tendencias depravadas de la carne» en otra pirueta informal de humor travieso: «No más beefteach, no más chuletas, no más ojos negros, no más talles elegantes; en una palabra, no más carne». Respecto a la Semana Santa, donde Bécquer se sentía a gusto depurando impresiones sensoriales — «ondas de luz, de sonidos y de perfumes»- o sensaciones fáusticas - «misteriosa música de las campanas de la vetusta catedral gótica que saludan el alba el día de la Resurrección»(MUS, 1866: 97)—, Galdós urdía un complejo cuadro moral, cargado de ironía, contra las pretensiones de santidad y contra la hipocresía, fantaseando con Tartuffe y Marta la piadosa caminando «a paso largo hacia la sacristía», en un contradictorio contexto madrileño plagado de incitaciones, que contenía en su seno los tres enemigos del alma: Madrid mundo, Madrid demonio, Madrid carne con el débil contrapunto de un Madrid fe: "Mucha devoción, pero mucha tentación. Por un lado, golpes de pecho, caras de Dios, setenarios, monumentos, estaciones; por otro, chismografía de historia, ambición que fascina y hornos del diablo que achicharran» (Shoemaker: 1972: 317). Incluso en los consabidos tópicos del tiempo, Galdós sobrepasaba en intención premeditada a un Bécquer que exteriorizaba en términos militares su sensación del invierno tardío «en sus últimas trincheras», desplegando todo su aparato de tonantes meteoros y quemando «los tempranos retoños de los árboles» (MUS, 1866: 81). Mientras, el revistero de La Nación (11 de marzo) insinuaba atrevidas analogías entre naturaleza y moral social remitiéndose festivamente al método inductivo. La naturaleza lloraba sobre Madrid vergonzantes «lágrimas de mogigata» que lejos de limpiar enlodazaban la tierra formando sobre ella una pasta como de chocolate que adquiría "el aspecto de una inmensa piedra estereotípica» donde se grababa «fielmente la marcha de la sociedad madrileña. [...] No sería difícil encontrar relación entre las huellas de un zapato y el espíritu de un pueblo». En la segunda quincena de abril, la crisis bursátil — «barómetro de la política»— suscitaba en Bécquer reacciones huidizas, vagas insinuaciones sobre «los especuladores del miedo» y confianza en el espíritu de progreso llegando a la evasiva argumentación de que para «naciones como la nuestra» las contrariedades y obstáculos que afectaban a la Hacienda pública podían ser «causas providenciales» para redoblar esfuerzos y renovar la energía nacional «con más ardientes bríos». (MUS, 1866: 129). Galdós más concreto, fundiendo expresión literaria y alusiones económicas, tejía sátiras irónicas contra el optimismo y fábulas burlescas sobre la crisis financiera y 
las restricciones presupuestarias del ministro de Hacienda - «el de Burgos», Manuel Alonso Martínez, cesado el 28 de mayo- especie de alquimista que aceleraba el empobrecimiento colectivo: «La pobreza; mas no de uno, sino de todos los españoles, la bancarrota de una nación, la sublimidad del desfalco, el trueno reducido a su más augusta expresión». (Shoemaker, 1972: 323). Tanto Bécquer como Galdós jugaron a los vaticinios catastróficos. Gustavo anticipando conflictos en el teatro político europeo al que dedicaba la mayor parte de sus universales «revistas». Galdós, más inmediato, aludiendo el 3 de junio a la enigmática inmediatez de «la Gorda»: «¿Cuál es el significado de esta palabra? ¿Es cosa que se espera, que se teme o que se desea?». Su comentario sobre los temores de los madrileños y el cese de Alonso Martínez parecía presagiar la inminencia de graves acontecimientos de los que parecía estar en el secreto, envalentonado hasta el extremo de apuntar abiertamente contra el presediente del Consejo (17 de junio), descalificando su política, sin morderse la lengua al esbozar la exaltación figurada del magnicidio: «¿Quién será el Bruto de O’Donnell? Estos dictadores de papelón darían su título de duques, sus conocimientos estratégicos y gramaticales por topar con un Bruto que los inmortalizara». Su última «Revista» en La Nación satirizaba la contradicción entre la obligada proeza marítima de la escuadra española y la lucha parlamentaria contra el duque de Tetuán, parapetado en su «Callao» del banco azul y máximo oficiante de la Gran Pastelería Nacional donde se cocían contradictorios pasteles legislativos que conculcaban derechos civiles. En su caso, su condición partidista, su irreverencia juvenil ante lo establecido, su humor provocativo lleno de sobreentendidos para un lector afín, estimulaban su imaginación literaria.

El 1 de julio de 1866, tras el fracaso de la sublevación del Cuartel de San Gil y la sangrienta represión de los sargentos, ya con Galdós silenciado por la segunda suspensión gubernativa de La Nación y del resto de la prensa democrática, Bécquer glorificaba la guerra del Pacífico, argumentando que la sangre de los marinos españoles —vertida en «el ara santa de la patria», no ante el mezquino altar de los intereses partidistas- debía servir para fortalecer el espíritu nacional. Sobre la otra sangre sediciosa de los sesenta y seis sargentos conspiradores ejecutados tras la nueva frustración democrática del 22 de junio, poco pudo escribir el poeta, a no ser para mostrar su consternación y registrar, como era costumbre, con prudente retórica, su confianza en el restablecimiento del orden: «Con la confianza que renace, con la calma que se restablece y la inquietud de los ánimos que gradualmente se disipa, volverán sin duda alguna a ofrecer atractivo las cuestiones que se rozan con las letras, las artes y la industria momentáneamente relegadas al olvido ante el doloroso 
interés que despiertan tristes y deplorables acontecimientos». (MUS, 1866: 202).

Prosa nueva y prosa vieja, ilusión revolucionaria y transigencia desengañada, Galdós y Bécquer. La agilidad del lenguaje periodístico del más joven bien pudo ser el resultado de muy provechosas lecciones de Quevedo y de Larra, pero hubo momentos de extrema brillantez en que sus hallazgos expresivos germinaron en una prosa connotativa de nuevo cuño que condensaba la tradición satírica de la prensa española de la primera mitad de siglo, matizada por la lectura de Charivari, del Punch o de Gil Blas. Sus últimas «revistas» de 1866 se fragmentaban formalmente en secuencias numeradas, entre súbitos destellos de ingenio, paradojas, dardos irónicos, oblicuidad metafórica, recurso al leitmotiv con efectos rítmicos, mientras que Gustavo construía textos más homogéneos y previsibles, sustentados en recurrencias y encadenamientos que prolongaban la expansión sintáctica, no exentos de una discreta elegancia pero bajo modelos expositivos que encorsetaban su inventiva en el frágil epílogo de la desarticulación romántica.

Bécquer y Galdós como revisteros de actualidad dieron pasos dispares pero complementarios en el continuo fluir de la creatividad literaria, desbordada del libro a los papeles periódicos con el desarrollo de la sociedad liberal. El modelo ecléctico que practicaron en sus «Revistas de la Semana», mixto de noticias y de imaginación, todavía persistió después de 1868 en las grandes revistas ilustradas y en los suplementos literarios de Madrid y de Barcelona. Pero dicho modelo se fue disolviendo ante las visiones más personales del ego que — siguiendo las huellas modernizadoras de la prensa europea- dieron lugar a una nueva propuesta comunicativa popularizada con el histórico marbete de «crónica», donde el discurso del emisor crecía sustentado en la seducción cautivadora del estilo literario, cosa que se hizo mucho más patente cuando el nuevo género se asentó en la prensa diaria con la llegada de la «gente nueva» en los últimos años del siglo.

\section{Bibliografía}

Alonso, Cecilio, (2009) «Imágenes de Galdós en la prensa entre dos siglos». Actas del VIII Congreso Internacional galdosiano 2005, Las Palmas, Cabildo de Gran Canaria, pp. 66-116.

HoAr, Leo J., (1968) Benito Pérez Galdós y la Revista del Movimiento Intelectual de Europa. Madrid, 1865-1867, Madrid, Ínsula.

ORTEGA, Marie-Linda (2003), La tarea conjunta de los hermanos Bécquer en El Museo Universal (1862-1869), Berna, Peter Lang. 
PÉrez VidAl, José (1987), Galdós. Años de Aprendizaje en Madrid, 1862-1868, Santa Cruz de Tenerife, Vicepresidencia del Gobierno de Canarias.

Piudo Moreno, María (1971), El Laberinto (Madrid 1843-1845), Madrid: CSIC, Colección de Índices de Publicaciones periódicas, XXI.

RIEGO, Bernardo (2001a), La construcción social de la realidad a través de la fotografía y el grabado informativo en la España del siglo XIX, Santander, Universidad de Cantabria, pp. 95-284.

RiEGO, Bernardo (2001b), «La Campaña de África de 1859. Primera guerra mediática española», Comunicación, Historia y Sociedad. Homenaje a Alfonso Braojos, ed. de Eloy Arias y otros, Sevilla, Secretariado de Publicaciones de la Universidad de Sevilla, pp. 563-575.

RODRÍGUEZ SEBASTIAN, Borja (2012), «Ramón de Navarrete y Misterios del corazón (1845): ciudad del lujo y del glamour», Anales de Literatura Española, 24 (Serie monográfica, n. $^{\circ}$ 14): Literatura y espacio urbano, ed. de $\mathrm{M}^{\mathrm{a}}$ de los Ángeles Ayala, Universidad de Alicante, Área de Literatura Española, pp. 43-66.

Rubio Cremades, Enrique (1977-1979), Costumbrismo y folletín. Vida y obra de Antonio Flores, Alicante, Instituto de Estudios Alicantinos. Diputación Provincial, 3 vols.

Rubio Cremades, Enrique (1995), Periodismo y Literatura: Ramón de Mesonero Romanos y El Semanario Pintoresco Español, Alicante, Generalitat Valenciana/ Institut de Cultura Juan Gil-Albert (Diputació d'Alacant).

Rubio CREmades, Enrique (2009) «El crimen de Villaviciosa», de Ramón de Navarrete. Entre la crónica de sociedad y el relato de misterio. Anales de Literatura Española, 20 (2008), Universidad de Alicante, Área de Literatura Española, pp.. 285-301.

SHOEMAKeR, William H. (1972), Los artículos de Galdós en «La Nación» 18651866, 1868, Madrid, Ínsula.

\section{Fuentes periodísticas consultadas}

Fénix, El. Semanario valenciano [Periódico Universal Literario y Pintoresco], (FÉN), Valencia, 1845-1849.

Ilustración. Periódico Universal, La, (ILU), Madrid, 1849-1857.

Laberinto, El. Periódico Universal, (LAB), Madrid, 1843-1845.

Museo de las Familias, (MdlF), Madrid, 1849.

Museo Universal, El, (MUS), Madrid, 1857-1869.

Semana. Periódico Pintoresco Universal, La, (SEM), Madrid, 1849-1850.

Semanario Pintoresco Español, (SPE), Madrid, 1846.

Siglo Pintoresco. Periódico Universal, El, (ESP), Madrid, 1844-1847.

Fecha de recepción: 28/06/2013

Fecha de aceptación: 02/09/2013 